\title{
Synthesis of Ionic Imprinted Polymer Particles for Selective Membrane Transport of Fe(III) using Polyeugenol as the Functional Polymer
}

\author{
MUHAMMAD CHOLID DJUNAIDI ${ }^{1,2 *}$, JUMINA², \\ DWI SISWANTA ${ }^{2}$ and MATHIAS ULBRICHT ${ }^{3}$
${ }^{1}$ Department of Chemistry, Faculty of Science and Mathematics, Diponegoro University, Indonesia. ${ }^{2}$ Department of Chemistry, Faculty of Mathematics and Natural Sciences, Gadjah Mada University, Indonesia.
${ }^{3}$ Lehrstuhl für Technische Chemie II, Fakultat fur Chemie, University at Duisburg-Essen, Essen, Germany
${ }^{*}$ Corresponding author E-mail: choliddjunaidi @live.undip.ac.id \\ http://dx.doi.org/10.13005/ojc/320107
}

(Received: January 02, 2016; Accepted: March 07, 2016)

\begin{abstract}
The preparation of lonic Imprinted Polymer (IIP) particles for selective membrane transport of Fe (III) had been done using polyeugenol as functional polymer and PVA (polyvinyl alcohol) (Mr $125,000)$ solution in 1-Methyl-2-pyrrolidone (NMP) solvent as membrane base. The membrane was then cut and Fe(III) was removed by acid to produce IIP particles membrane. Analysis of the membrane and its constituent was done by IR, SEM and also TOC analysis. Experimental results showed the transport of $\mathrm{Fe}(\mathrm{III})$ was faster with the decrease of membrane thickness and the higher concentration of template. However, the transport of $\mathrm{Fe}(\mathrm{III})$ was slower for higher concentration of PVA (Polyvinyl Alcohol) in the membrane. The selectivity of all IIP particles membrane was confirmed as they were all unable to transport $\mathrm{Cr}$ (III), while NIP (Non-imprinted Polymer) membrane was able transport $\mathrm{Cr}(\mathrm{III})$.
\end{abstract}

Key words: IIP Particles Membrane, Selective Transport, Crosslinking, Polyeugenol.

\section{INTRODUCTION}

Considerable attention has been given to molecularly imprinted polymer (MIP) technology today, which leads to the increase of its application in many different fields of research ranging from filtration, chromatography, sensor ${ }^{1}$, racemic mixture purification, as well as controlled catalytic complex chemical reaction ${ }^{2}$.

Today, heavy metal imprinted adsorbents used for the separation of selective heavy metal 
have attracted more attention, one of which is for the separation of Fe (III) ${ }^{3-4}$. The development of inexpensive adsorbent with high adsorption capacity had been the main goal of many studies. One interesting study is the use of biomaterials as adsorbent for heavy metal waste ${ }^{5,6}$. Biomaterials are very important because it is cheap and biodegradable, as well as biocompatible. They can be prepared from a number of different agricultural waste, such as corn husk, bagase, rice husk, lignin, microbial biomass, chitosan ${ }^{7,8}$,husk of green gram (phaseolusaureus) seed ${ }^{9}$ and eugenol. Eugenol is one of native Indonesian natural products and has many purposes, including for the separation of metal ions. Some examples are the conversion of eugenol into polyeugeniloxyacetate was used for the separation of heavy metal mixtures by solvent extraction method ${ }^{10}$, and its conversion into eugenoxy acetate for the separation of $\mathrm{Cr}$ (III) using Bulk Liquid Membrane (BLM) method ${ }^{11}$. Eugenol polymer, polyeugenol, has been used as a BLM carrier with the order of $\mathrm{Cr}(\mathrm{III})>>\mathrm{Fe}(\mathrm{III})>\mathrm{Ni}(\mathrm{II}) \mathrm{Zn}>>\mathrm{Cd}$ (hard>medium $>$ soft) ${ }^{12}$. Djunaidi et al (2015) used polyeugenol as a functional polymer of IIP (Ionic Imprinted Polymer) method for selective adsorption of $\mathrm{Fe}(\mathrm{III})^{13,14}$.

In the last decade, imprinting techniques is used for the build up of molecularly imprinted membranes (MIMs) that can selectively recognize target molecule in a solution during a simple static adsorption as well as permeation through a membrane device ${ }^{15}$.Djunaidi et al (2015) also synthesized IIP Fe membrane via simultaneous formation of IIP stucture and morphology (in situ) by used polyeugenol as a functional polymer ${ }^{16}$.

The term membrane is used to describe an interface between two adjacent phases which acts as a selective barrier and control the transport between the two compartments ${ }^{17-18}$.A MIM is a membrane either composed of a MIP or containing a MIP ${ }^{19}$. In the present study, the synthesis of MIM (IIM) from IIP particles had been studied. Membrane preparation was preceded by the synthesis of IIP $\mathrm{Fe}(\mathrm{III})$ using polyeugenol as the functional polymer and PEGDE as the crosslinker. The IIP was then used to synthesize the membrane using PVA as the membrane base. PVA membranes usually display high stability in strongly acidic and alkaline environments ${ }^{20}$.

\section{EXPERIMENT}

\section{Instruments}

The instruments used in this study are pH-meter, magnetic stirrer, separatory funnel, glasswares and plastic wares, analytical balance (Mettler Toledo AB54-S), three-necked flask, casting machine (Erichsen), FTIR Spectrophotometer (Jasco Miracle ATR), XRD (Shimadzu XRD-8000), AAS (Atomic Absorption Spectrophotometry (Shimadzu 8201PC), UV visible 50 Probe, TOC- (Total Organic Carbon)-analyser (SHIMADZU),SEM EDX (JSM 6380 LA), a set of difussion transport cell..

\section{MATERIALS}

The materials used in this study are Eugenol, $\mathrm{BF}_{3} \mathrm{O}\left(\mathrm{C}_{2} \mathrm{H}_{5}\right)_{2}$ and PEGDE (Polyethyleneglycoldiglycidylether) that were purchased from SIGMA-Aldricht, 1 Methyl 2 pyrrolidone and $\mathrm{Fe}(\mathrm{III})$ nitrat nonahydrate were purchased from Fluka, $\mathrm{NaOH}, \mathrm{HCl}$, polyvinylalcohol (PVA, Aldricht Mr. 125000), aquademineralized (Milli-Q).

\section{Synthesis of Polymers Polyeugenol}

Eugenol (5.8 g) was put in a 3-necked flask, then $0.25 \mathrm{~mL}$ of boron trifluoride diethyl ether, $\mathrm{BF}_{3} \mathrm{O}\left(\mathrm{C}_{2} \mathrm{H}_{5}\right)_{2}$ was added as catalyst. The addition was done 4 times every hour while stirring with magnetic stirrer at room temperature. The occurrence of a reaction can be characterized by the color change of the solution into red. After the last addition of the catalyst, the polymerization was allowed to continue up to 12-16 hours, after which $1 \mathrm{~mL}$ of methanol was added to stop the reaction. The gel produced was dissolved in chloroform and put into a separating funnel and then washed repeatedly with distilled water until neutral. The organic layer was transferred into a $50 \mathrm{~mL}$ erlenmeyer flask and added with anhydrous $\mathrm{Na}_{2} \mathrm{SO}_{4}$. The liquid was separated by decantation. Afterwards, the solvent was evaporated in rotary evaporator at $40^{\circ} \mathrm{C}$. The residue obtained was further dried in the desiccator, 
and was subsequently weighed and characterized using FT-IR.

\section{Synthesis of IIP-Fe(III) Particles Membrane}

Polyeugenol $(0.5 \mathrm{~g})$ was stirred with (Fe (III) solution with different concentrations for 24 hours. The product was filtered with a filter paper and subsequently air dried at room temperature. $0.3 \mathrm{~g}$ of Polyeugenol-Fe(III) produced from this process was then crosslinked using PEGDE as the crosslinker with a mole ratio of $1: 1$ by heating for 15 minutes at $80-90{ }^{\circ} \mathrm{C}$ with $20 \mathrm{~mL} 1 \mathrm{M} \mathrm{NaOH}$ as catalyst. The product was then neutralized and dried at $115^{\circ} \mathrm{C}$ in an oven for 6 hours. The polymer produced was further treated with acid for 24 hours to release the $\mathrm{Fe}(\mathrm{III})$ ions and form the final product of IIP-Fe(III) polymer.

\section{The preparation of IIP particles membrane}

$0.25 \mathrm{~g}$ of IIP Fe was added with $0.5 \mathrm{~g}$ PVA (weight ratio of IIP:PVA was 1:2) and dissolved in 7 $\mathrm{mL} N M P$ and then heated at $100-110^{\circ} \mathrm{C}$ for 4 hours. Next, casting was carried out at $25 \mathrm{~m} / \mathrm{s}$ on a glass layer. The casting layer was then dried in an oven at $80^{\circ} \mathrm{C}$ overnight. The membrane produced was then coagulated in $1 \mathrm{M} \mathrm{NaOH}$ solution overnight. The membrane sheet obtained was cut and subsequently washed with demineralized water and the template was then leached using $0.1 \mathrm{M} \mathrm{HCl}$ overnight and mounted onto the ring of the diffusion cell.

\section{Synthesis of Non-Imprinting Polymer (NIP) membrane}

NIP was synthesized using similar method as the synthesis of MIP, excluding the step of $\mathrm{Fe}(\mathrm{III})$ binding to the polymer.

\section{Transport of $\mathrm{Fe}(\mathrm{III})$ ion through the membrane}

The transport of $\mathrm{Fe}(\mathrm{III})$ ion through the membrane was carried out in a difussion cell, using $50 \mathrm{~mL} \mathrm{Fe}($ III) solution at $325 \mathrm{mg} / \mathrm{L}$ in the feed phase (pH 3).

\section{Performance test for the Fe(III) IIP particles membrane}

Optimization of $\mathrm{Fe}$ (III) IIP membrane performance was done for different membrane thickness, templates and PVA weight.

\section{Selectivity test for IIP particles membrane}

The selectivity of IIP membrane was compared to that of NIP membrane and the test was carried out using $50 \mathrm{mg} / \mathrm{L} \mathrm{Cr}(\mathrm{III})$ solution $(\mathrm{pH} 3)$ in separate systems.

\section{Total Organic Carbon (TOC) measurement}

Diffusion measurements were performed to determine the rate of diffusion through the corresponding membranes (effective diffusion coefficient) and the solute fractionation under these conditions. This measurement was carried out using a diffusion cell composed of two half-cells. The membrane was fixed between these half-cells with the membrane side. The two half cells were filled at the same time to the same height level with receiving solution (50 $\mathrm{ml}$ water) and feed solution (10 $\mathrm{g} / \mathrm{l}$ equimass mixture of dextrans with average

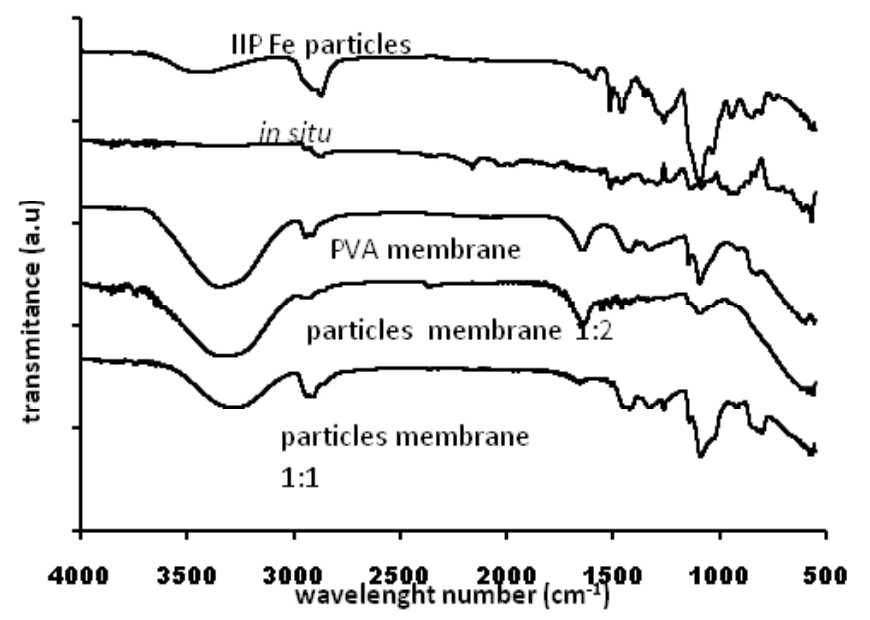

Fig. 1: Infrared spectra of MIM particles membrane and its components 
molecular weight of 15000 until 20000 (dextran 15 in $50 \mathrm{ml}$ water) and stirred at the same stirring rate. The diffusion of dextran through the membrane was monitored by measuring the concentrations using TOC in both half-cells at 24 hours.

\section{Contact Angle measurement}

Contact Angle was measured by microscope instrument and then counted manually.

\section{Analysis of $\mathrm{Fe}(\mathrm{III})$}

The analysis of $\mathrm{Fe}(\mathrm{III})$ was done by UVvisible spectrophometer using $\mathrm{KSCN}$ reagent at $458 \mathrm{~nm}$ and Atomic Absorption Spectrophotometry (AAS).

\section{Analysis of $\mathrm{Cr}(\mathrm{III})$ with UV-Visible spectrophotometer}

The analysis of $\mathrm{Cr}(\mathrm{III})$ was done by UVVisible spectroscopy at $420 \mathrm{~nm}$.

\section{RESULTS AND DISCUSSIONS}

\section{Synthesis of IIP Fe Particles membrane}

The results of synthesis of IIP Fe particles membrane were then characterized using FTIR. From Figure 1 it can be seen that the spectra for particles membrane can be seen as a combination of MIP particles and PVA membane spectra. The spectra of the particles membrane with weight ratio of $1: 2$ is dominated by PVA absorption characteristics, while the one with weight ratio of $1: 1$ is dominated by the characteristics of poly-PEGDE adsorbent particles, especially for wavenumber of $1100 \mathrm{~cm}^{-1}$, which is the typical absorption band for C-O of glycidyl ether. The spectra are different from that of in situ membrane as there are spectral shift due to new bonds being formed in the latter ${ }^{15}$.

The transport of $\mathrm{Fe}(\mathrm{III})$ in the IIP particles membrane

The study of $\mathrm{Fe}(\mathrm{III})$ transport was carried out through a series of experiments using $25 \mathrm{mg} / \mathrm{L}$ $\mathrm{Fe}$ (III) solution at $\mathrm{pH} 3$ and $0.1 \mathrm{HCl}$ solution as the stripping phase. The result of Fe (III) transport from the feed phase to the stripping phase can be seen in Figure 2.

It can be seen in Figure 2 that the concentration of $\mathrm{Fe}(\mathrm{III})$ in the feed phase decreased with time as $\mathrm{Fe}(\mathrm{III})$ was transported to the stripping phase so that the concentration of $\mathrm{Fe}(\mathrm{III})$ in the stripping phase increased with time.

\section{Membrane thickness variation}

The effects of membrane thickness on membrane selectivity and flux had been studied by other researchers. Binning et al. had observed that the flux of $n$-heptane and isooctane mixture (50/50 $\%$ vol) through a plastic membrane is inversely proportional with membrane thickness and selectivity and was not affected by membrane thickness for the range of $20-50 \mu \mathrm{m}^{20}$.

Therefore, to optimize the performence of the membrane, thiner membrane $(300 \mu \mathrm{m})$ needs to
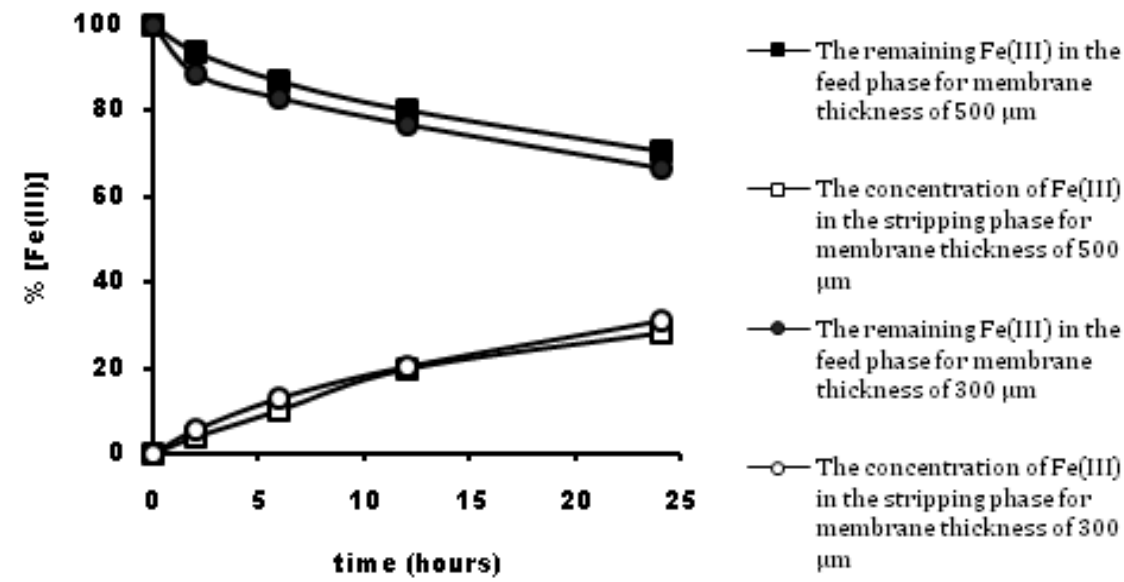

Fig. 2: The transport of $25 \mathrm{mg} / \mathrm{L} \mathrm{Fe(III)} \mathrm{solution} \mathrm{through} \mathrm{IIP} \mathrm{particles} \mathrm{membrane}$ (weight ratio of IIP: PVA equals to 2:1) with membrane thickness of 300 and $500 \mu \mathrm{m}$ 
be synthesized. The results of $\mathrm{Fe}(\mathrm{III})$ transport using this membrane can be seen in Figure 2.

From Figure 2, it can be seen that for the membrane with membrane thickness of $300 \mu \mathrm{m}$, $\mathrm{Fe}(\mathrm{III})$ being transported to the stripping phase is higher than that of $500 \mu \mathrm{m}$ membrane, which means that the amount of $\mathrm{Fe}$ (III) being trapped in the membrane is smaller. It indicates that the smaller thickness of membrane the higher \% transport Fe(III) to stripping phase.

\section{Variation of Concentration of Template}

Template is one of the most important parts of IIP ${ }^{13}$ and also IIP membrane in situ ${ }^{16}$ as well IIP particles, as ilustrated in Figure 3.

Figure 3. Transport percentage of $\mathrm{Fe}(\mathrm{III})$ in the feed phase and stripping phase for $300 \mu \mathrm{m}$ membrane with different template. It can be seen in Figure 3 that the transport percentage of $\mathrm{Fe}$ (III) from the feed phase increased with increasing template concentration for $300 \mu \mathrm{m}$ membranes. Interestingly, the concentration of $\mathrm{Fe}(\mathrm{III})$ in the stripping phase decreased with increasing template concentration, which suggests that at higher template concentration, more imprinted caves were formed in the membrane which resulted in stronger interactions between the membrane and $\mathrm{Fe}(\mathrm{III})$ ions, so that the ions are more difficult to be released. This happened probably because IIP particles membrane works through retarded permeation mechanism ${ }^{17-18}$.

\section{Variation of membrane base (PVA) amount}

To determine the effects of membrane base (PVA) amount on transport of Fe a series of $\mathrm{Fe}$ (III) transport experiments were carried out for IIP particles membrane synthesized with different PVA concentration. The weight ratio used for IIP polymer: PVA were 1:2 and 1:1, and the transport experiments results can be seen in Figure 4-5.

It can be seen from Figures 4-5 that the transport percentage of $\mathrm{Fe}(\mathrm{III})$ in the stripping phase increased and decreasing in feed phase with decreasing PVA concentration.

\section{Scaning Electron Microscope (SEM)}

The complete results form SEM analysis are shown in Figure 6.
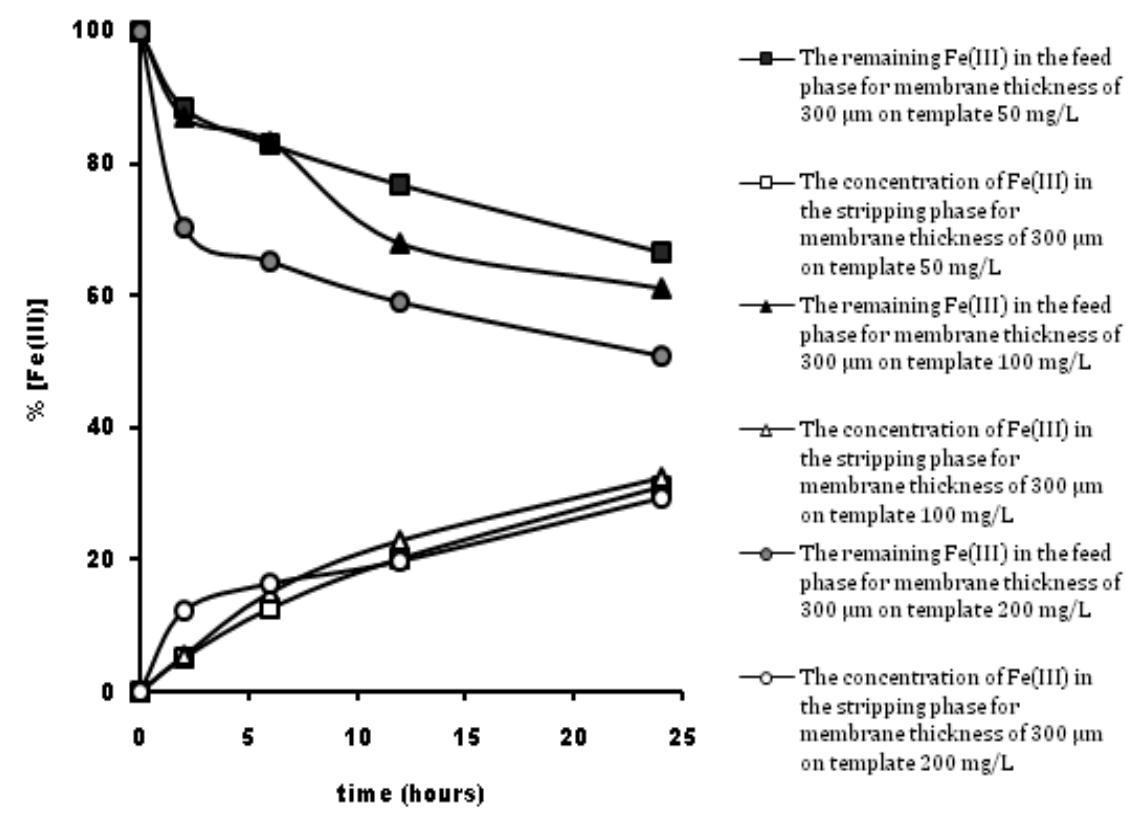

Fig. 3: Transport percentage of $\mathrm{Fe}(\mathrm{III})$ in the feed phase and stripping phase for $\mathbf{3 0 0} \mu \mathrm{m}$ membrane with different template 
As can be seen in Figure 6, the particles membrane appeared to be solid and unporous as well as symmetical. This is probably because the pores in IIP are blocked by the membrane base (PVA). This result was confirmed by the results obtained from size selective analysis using TOC analysis.

Table 1: Size selective analysis using TOC

\begin{tabular}{lcc}
\hline $\begin{array}{l}\text { Types of } \\
\text { membrane } \\
(\mathbf{3 0 0} \boldsymbol{\mu m})\end{array}$ & $\begin{array}{c}\text { TOC } \\
\text { \% dextran } \\
\text { remaining in the } \\
\text { feed phase }\end{array}$ & $\begin{array}{c}\text { \% dextran in } \\
\text { the water } \\
\text { phase }\end{array}$ \\
\hline $\begin{array}{l}\text { Membrane } \\
\text { template } 200\end{array}$ & 99.42 & 0.58 \\
NIP & 93.76 & 0.98 \\
\hline
\end{tabular}

Table 2: Contact Angle of different Particles membrane

\begin{tabular}{lc}
\hline Membrane Types & Contact Angle \\
\hline Membrane 1:2 thickness $300 \mu \mathrm{m}$ & $45-50^{\circ}$ \\
Membran 1:2 thickness $500 \mu \mathrm{m}$ & $50-60^{\circ}$ \\
Membran 1:1 thickness $500 \mu \mathrm{m}$ & $50^{\circ}$ \\
\hline
\end{tabular}

As shown in Table 1, the membrane with $200 \mathrm{mg} / \mathrm{L}$ template could barely transport dextran 15, while NIP was able to transport almost $6 \%$ of dextran 15. This means that the particles membrane are nearly poreless, while the pores in NIP is larger that those in the membrane template 200 particles.

As shown table 2 the thicker membrane the greater the contact angle, these happened probably because the more content of the membrane. These contact angle value were similar to the contact angle of the IIP membrane in situ ${ }^{16}$.

\section{Membrane selectivity}

The selectivity of the membrane was determined using $25 \mathrm{mg} / \mathrm{L}$ of $\mathrm{Cr}$ (III) solution. $\mathrm{Cr}$ (III) was selected because it has the same charge as $\mathrm{Fe}(\mathrm{III})$ and thus is expected to have similar charge density as well as ionic radius to $\mathrm{Fe}(\mathrm{III})^{4}$. The result

Table 3: Transport percentage of $\mathrm{Cr}(\mathrm{III})$ for different particles membrane

\begin{tabular}{lc}
\hline $\begin{array}{l}\text { Type of membrane } \\
\text { (IIP particles with } 300 \mu \mathrm{m} \\
\text { and weight ratio of 1:2) }\end{array}$ & $\begin{array}{c}\text { \% tranport of } \\
\text { Cr(III) }\end{array}$ \\
\hline NIP & 12.97 \\
Membrane template 50 & 0 \\
Membrane template 100 & 0 \\
Membrane template 200 & 0 \\
\hline
\end{tabular}

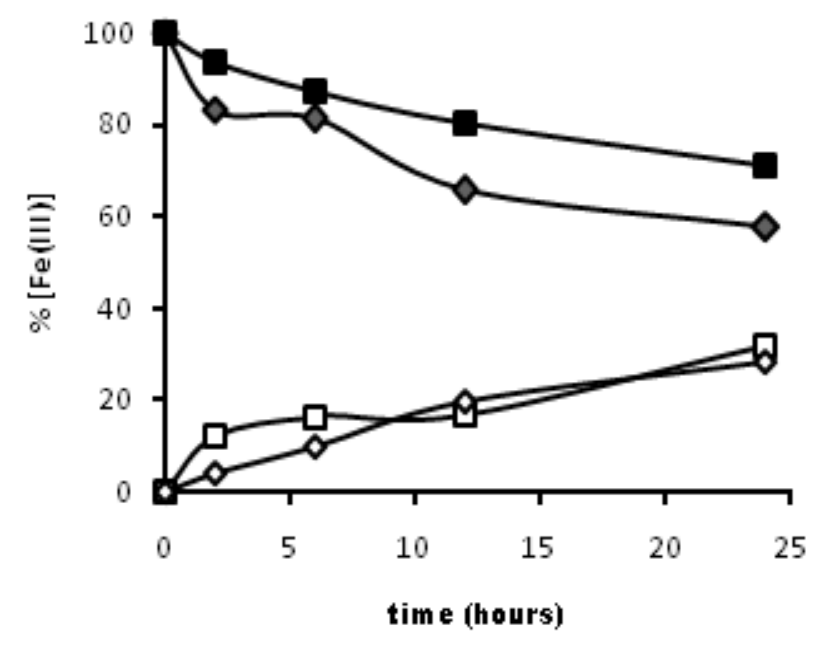
$\longrightarrow$ The remaining $\mathrm{Fe}(\mathrm{III})$ in the feed phase for membrane thickness of $500 \mu \mathrm{m}$ on template $50 \mathrm{mg} / \mathrm{L} 1: 1$
$\rightarrow-$ The concentration of $\mathrm{Fe}(\mathrm{III})$ in the stripping phase for membrane thickness of $500 \mu \mathrm{m}$ on template $50 \mathrm{mg} / \mathrm{L} 1: 1$
- The remaining $\mathrm{Fe}(\mathrm{III})$ in the feed phase for membrane thickness of $500 \mu \mathrm{m}$ on template $50 \mathrm{mg} / \mathrm{L} 1: 2$
$\neg$ The concentration of $\mathrm{Fe}(\mathrm{III})$ in the stripping phase for membrane thickness of $500 \mu \mathrm{m}$ on template $50 \mathrm{mg} / \mathrm{L} 1: 2$

Fig. 4: The comparison of $\mathrm{Fe}(\mathrm{III})$ transport percentage in the feed phase and stripping phase for membrane $50500 \mu \mathrm{m} \mathrm{1:2}$ and 1:1. 


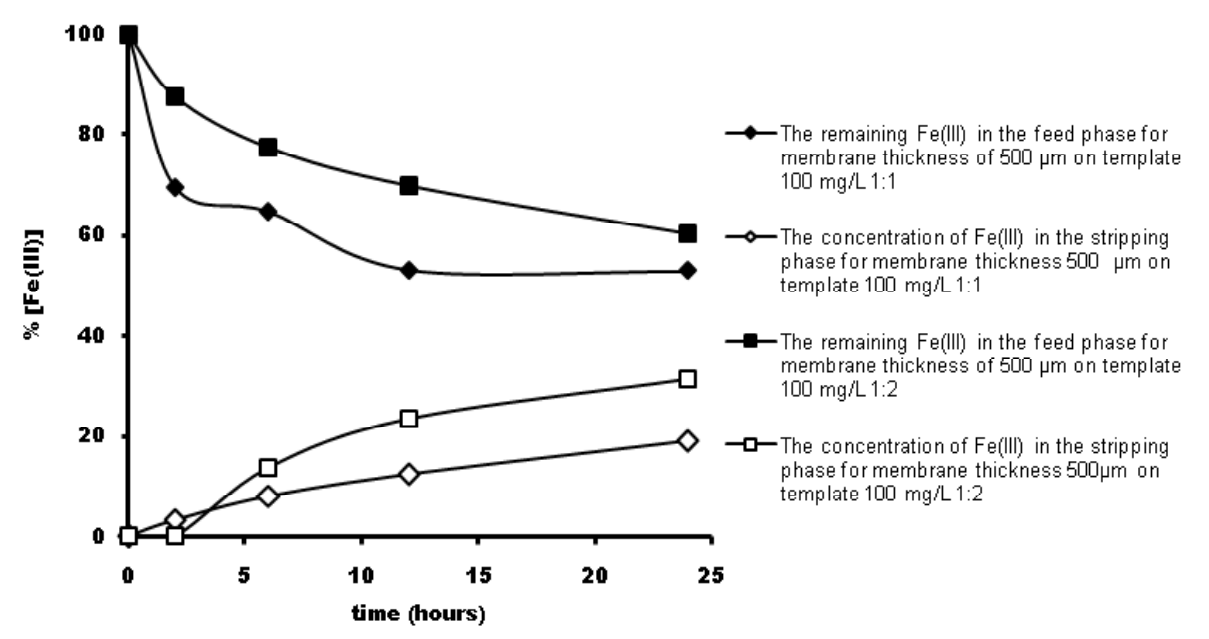

Fig. 5: The comparison of Fe(III) transport percentage in the feed phase and stripping phase for membrane $100500 \mu \mathrm{m} \mathrm{1:2}$ and 1:1

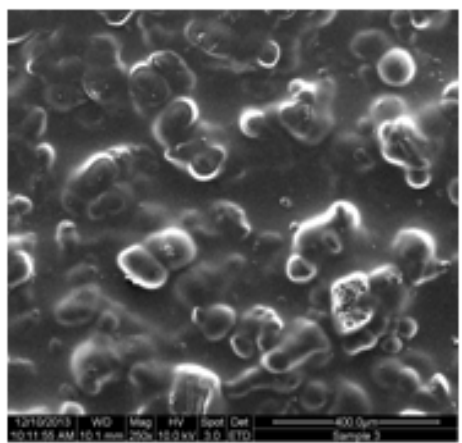

(a) front side of the membrane template $50500 \mu \mathrm{m}$ after transport of $\mathrm{Fe}(\mathrm{III})(8000 x$ magnification)

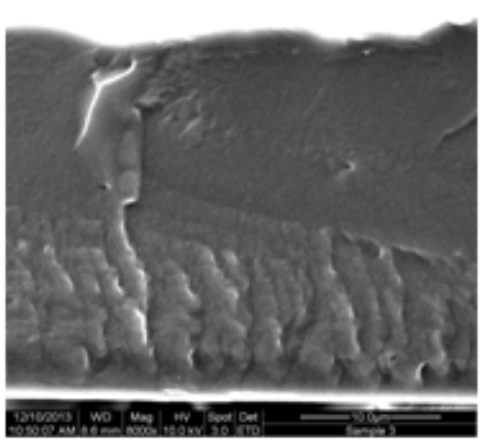

(b) cross section of membran template $50500 \mu \mathrm{m}$ after transport Fe(III) (250x magnification)

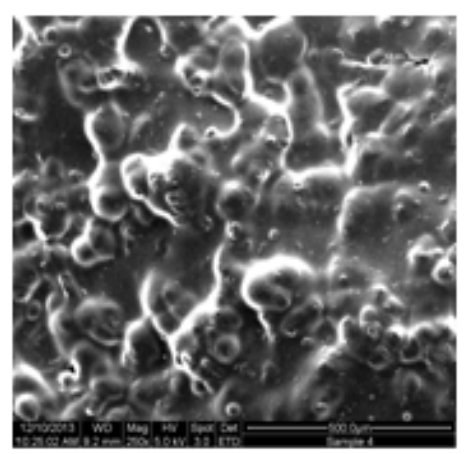

(c). Front side of membrane template $100500 \mu \mathrm{m}$ after transport of $\mathrm{Fe}(\mathrm{III})(250 \mathrm{x}$ magnification)

Fig. 6: The results from SEM analysis of IIP particles membrane

obtained from the selectivity study can be seen in Table 1.

As shown in Table 1, none of the MIMs was able to transport $\mathrm{Cr}(\mathrm{III})$, while NIP was still still able to transport $\mathrm{Cr}$ (III) to a certain extent, indicating the selectivity of MIMs synthesized in our study

\section{CONCLUSIONS}

MIM Fe (IIM Fe) particles prepared from PVA as membrane base, IIP particles and polyeugenol as functional polymer and NMP as solvent can be used for the transport of $\mathrm{Fe}(\mathrm{III})$. A number of factors were found to influence the performance of the MIM particles being synthesized, such as membrane thickness, template ion concentration, and the weight of the membrane base (PVA) used in the synthesis. The flux of $\mathrm{Fe}(\mathrm{III})$ was found to increase with the decrease of membrane thickness and the weight of the membrane base. In addition, The MIM particles synthesized is also selective, as demonstrated by the selectivity test using $\mathrm{Cr}(\mathrm{III})$, in which $\mathrm{Cr}$ (III) could not be transported, while NIP was able to transport some of the $\mathrm{Cr}(\mathrm{III})$ ions 


\section{ACKNOWLEDGMENT}

1. The first author would like to express sincere gratitude to the Government of the Republic of Indonesia for the Sandwich Program and Competitive Grant.
2. The first author would like to also express sincere gratitude to the members of the group of Prof. Mathias Ulbricht because this research was mostly done during his stay at the University Duisburg-Essen.

\section{REFERENCES}

1. Trotta, F., Biasizzo, M., Caldera, F.,. 11. Membranes,2012, 2, 440-477. 2. Mahony, J.O., Nolan, K., Smyth, M.R.,
Mizaikoff, B., Anal. Chim. Acta.2005, 534, 31-39.

3. Chang, X, Jiang, N, Zheng, $\mathrm{H}, \mathrm{He}, \mathrm{Q}, \mathrm{Hu}, \mathrm{Z}$, Zhai, Y, Chui, Y., Talanta,2007, 7,38-43.

4. Xie, F., Lu, G., Wu, F., Guo, G., Li, G. Chem. Eng.,2012, 183, 372-380

5. Sölener, M., Tunali, S., özcan A.S., özcan, A., and Gedikbey, T.,Desalination, 2008, 223 (1-3), 308-322.

6. Guibal, E., Sep. Purif. Technol., 2004,38 (1), 43-74.

7. Copello, G.J., Varela, F., Vivot, M., and Diaz, L.E., Bioresour. Technol., 2008,99 (14), 6538-6544.

8. Miretzky, P., and Cirelli, A.F., J. Hazard. Mater.,2009, 167 (1-3), 10-23

9. Jirekar, D.B.; Pathan, A.A.; Farooqui, M. Oriental Journal of Chemistry, 2014, 30 (3), 1263-1269

10. Harimu, L, Matsjeh, S., Siswanta, D., Santoso, S.J., Indones J. Chem, 2009, 9(2), 261-266
11. Djunaidi, M.C., Khabibi, Trisna, D.JSKA, 2010, 13, 2

12. Djunaidi, MC, Lusiana, RA, Wibowa, PJ, Siswanta, Dwi, Jumina, J. Alchemy. , 2007,6, 40-49.

13. Djunaidi, M.C, Jumina, Siswanta, D., Ulbricht, M.,Indones. J. Chem.,2015, 15 (3)305 - 314.

14. Djunaidi, M.C.,Jumina. Siswanta, D., Oriental Journal of Chemistry, 2015, 31(4), 22232229.

15. Algeiri, C., Drioli, E., Guzzo, L, Donato, L., Sensors,2014, 14, 13863-13912.

16. Djunaidi, M.C, Jumina, Siswanta, D., Ulbricht, M., Asian J. Chem., 2015, 27 (12), p. 4553 4562

17. Ulbricht, M., Polymer,2006, 47, 2217-2262.

18. Ulbricht, M, J. Chromatogr, B., 2004, 804, 113-125.

19. Rhim, Ji-Won, Park, H.B., Lee, C.S., Jun, J.H, Kim, D.S., Lee, Y.M., , J. Membran Sci., 2004,238,143-151.

20. Villaluenga, J.P.G., Khayet, M., Godino, P., Seoane, B., Mengual, J.I..Separation and Purification Technology,2005,47, 80-87. 